\title{
Kodeks magistra Hieronima Szwarca. Przyczynek do dziejów najstarszego księgozbioru bernardynów w Krakowie
}

Streszczenie. Artykuł ma na celu pokazanie na przykładzie jednego kodeksu średniowiecznego wartości i znaczenia badań proweniencyjnych księgozbiorów historycznych. Przedmiotem charakterystyki jest średniowieczny kodeks ze zbiorów Biblioteki Uniwersyteckiej w Poznaniu - XV-wieczny odpis Catholiconu Giovanniego Balbi da Genova, popularnego w średniowieczu podręcznika gramatyki łacińskiej. Rękopis ukończony w 1457 roku, skromnie iluminowany, jest jedynym w zbiorach Biblioteki przykładem rękopiśmiennej księgi łańcuchowej (liber catenatus). Kodeks ten jest unikatowy i cenny ze względu nie tyle na treść, ile na osobę pierwszego właściciela (być może także kopisty księgi) - Hieronima Szwarca, magistra atrium Uniwersytetu Jagiellońskiego i późniejszego zakonnika w klasztorze franciszkanów obserwantów (bernardynów) w Krakowie na Stradomiu. Jak wynika z analizy zapisków proweniencyjnych odnotowanych na przedniej części wyklejki oprawy $\mathrm{Ca}$ tholiconu oraz ze źródeł historiograficznych, uniwersyteckich i zakonnych, Hieronim był synem znanego mieszczanina krakowskiego Jerzego Szwarca, który na przełomie 1453 i 1454 roku gościł w swojej kamienicy przy rynku sławnego włoskiego kaznodzieję pokutnego i reformatora zakonu franciszkanów Jana Kapistrana oraz towarzyszących mu braci. Powyższe badania źródłowe dowiodły, że prezentowany kodeks był własnością (może nawet dziełem rąk) absolwenta Uniwersytetu Jagiellońskiego, a zarazem reprezentanta kapistrańczyków, tj. licznego grona krakowskich studentów, którzy pod wpływem kazań Jana Kapistrana wstąpili do zakonu franciszkanów obserwantów i pierwszego na ziemiach polskich klasztoru bernardynów, założonego w Krakowie w 1453 roku. Druga zapiska własnościowa na oprawie księgi przynosi z kolei informację, iż w 1466 roku kodeks magistra Hieronima został przekazany (przez właściciela?) do biblioteki krakowskiego klasztoru. Należy więc do najstarszego księgozbioru bernardyńskiego w Polsce.

SŁowa Kluczowe: Giovanni Balbi da Genova, Catholicon, Hieronim Szwarc, Kraków, bernardyni, uniwersytet krakowski w XV wieku, liber catenatus, kodeksy średniowieczne, rękopisy średniowieczne, badania proweniencyjne. 
Badania proweniencyjne księgozbiorów historycznych przechowywanych $\mathrm{w}$ bibliotekach polskich i zagranicznych przybrały $\mathrm{w}$ ciagu ostatnich lat na sile, zajmując ważne, jeśli nie pierwszorzędne miejsce wśród zagadnień podejmowanych przez historyków książki, bibliotekoznawców. Przedmiotem i celem badawczym staje się przede wszystkim rekonstrukcja bibliotek instytucji kościelnych, głównie klasztorów, oraz właścicieli prywatnych - przedstawicieli szlachty, magnaterii czy miejskiego patrycjatu. W trakcie identyfikacji not proweniencyjnych zawartych na oprawach i kartach tytułowych poszczególnych woluminów natrafia się nierzadko na zapiski osób bliżej nieznanych bądź nieudokumentowanych w innych źródłach. Takie noty nabierają szczególnego znaczenia jako wyjątkowy materiał źródłowy. Zdarza się bowiem, iż zapiska proweniencyjna książki kryje ślad historii swojego właściciela i staje się punktem wyjścia do dalszych poszukiwań biograficznych, które prowadzą niekiedy do interesujących odkryć i hipotez.

Przykładem księgi z historią ukrytą w zapiskach proweniencyjnych jest przechowywany w Bibliotece Uniwersyteckiej w Poznaniu XV-wieczny kodeks zawierający odpis Catholiconu - największego dzieła włoskiego dominikanina Giovanniego Balbi da Genova (il. 1, 3) ${ }^{1}$. Ukończona w 1286 roku Summa grammaticalis quae vocatur Catholicon to najpopularniejszy w średniowieczu słownik i zarazem kompendium gramatyki łacińskiej. Powielana w wielu odpisach, była też jedną z pierwszych książek drukowanych w Moguncji (pierwodruk w 1460 roku)². Rękopis poznański ukończony w 1457 roku $^{3}$ jest jednym z wielu zachowanych średniowiecznych odpisów Catholiconu 4 . Kodeks o wymiarach 30,5 x 20,5 cm, liczący

1 Biblioteka Uniwersytecka w Poznaniu (dalej: BU), Rkp. 1717: Johannes Januensis de Balbis, Summa grammaticalis. Inc. Prosodia quaedam pars grammaticae nuncupatur..., ff. 529. Zdigitalizowany w 2014 roku i dostępny online na stronie Wielkopolskiej Biblioteki Cyfrowej w ramach kolekcji Rękopisów średniowiecznych BU: http://www. wbc.poznan.pl/publication/383095.

2 O kontrowersjach badawczych wokół daty pierwszego wydania dzieła Balbusa oraz o drukach odbitych tzw. czcionką Catholiconu: A. Świerk, Moguncki „Catholicon” (GW, 3182) jako problem badawczy, „Biuletyn Biblioteki Jagiellońskiej” 1994, t. 44, s. 63-80; J. Pirożyński, Johannes Gutenberg i początki ery druku, Warszawa 2002, s. $103-109$.

3 Taką datę zawiera kolofon tekstu, k. 528: Sit tibi laus chr(ist)e quo(n)ia(m) explicit liber iste. Et est sc(ri)pt(us) et finit(us) in die Galli de An(n)o d(omi)ni Mi(llesim)o cccc l. vij $^{\circ}$ die solis xvj Octob(ris).

4 Między innymi cztery manuskrypty znajdują się w Paryżu: Bibliothèque nationale de France (sygn. lat.7656), Bibliothèque de la Sorbonne (5859), Bibliothèque de 1"Arsenal (978), Bibliothèque Mazarine (3796) oraz w wielu innych bibliotekach europejskich. 
529 kart, skromnie iluminowany ${ }^{5}$, nie budził dotąd większego zainteresowania badaczy, choć warto podkreślić, iż jest jedyną przechowywaną w zbiorach biblioteki rękopiśmienną księgą łańcuchową (liber catenatus) ${ }^{6}$. Wyjątkowość tego kodeksu tkwi jednak nie tyle w zawartości, ile w osobie jego właściciela - a być może także kopisty - Hieronima Szwarca ${ }^{7}$ z Krakowa, magistra artium Uniwersytetu Jagiellońskiego i zakonnika krakowskiego klasztoru franciszkanów obserwantów, zwanych w Polsce bernardynami ${ }^{8}$.

Powyższe fakty z życia Hieronima udało się ustalić, i częściowo zrekonstruować, na podstawie dwóch not własnościowych zapisanych na przedniej wyklejce oprawy (il. 2). Pierwsza, zajmująca większą część karty (środkową część wyklejki), jest rozbudowana i ma nietypowa, rzadko spotykaną formę. Składa się z sześciu wersów, z których cztery środkowe zostały zapisane niejako w odbiciu lustrzanym, w taki sposób, iż poszczególne wyrazy należy odczytywać od końca. Pierwsze spostrzeżenie, jakie nasuwa się na początku analizy tekstu9: Hieronim zapisał notę czterokrotnie, eksperymentując z grafią i szukając jak najstosowniejszej formy. Pierwsze wersje zostały przez pisarza przekreślone, dopiero czwartą uznał za odpowiednią.

Pierwszy wariant zapisany minuskułą gotycką (teksturą), regularnie (tj. od strony lewej), składa się z czterech wyrazów, przy czym ostatni jest niezrozumiały:

\section{Liber magistri Yeronimi srimesto (?)}

Pozostałe warianty noty zostały zapisane gotycką kapitałą przejściową. Wyrazy dwóch kolejnych wersów czytane od końca (ale we właściwej

5 Najbardziej okazały inicjał ze zdobieniem filigranowym na k. 1 w incipicie: Prosodia quaedam pars grammaticae nuncupatur... (il. 3).

6 U dołu tylnej oprawy kodeksu pozostało żelazne kółko, do którego przytwierdzony był łańcuch (il. 4). Drugi koniec łańcucha nawlekano na poziomy pręt, mocując go przy blacie pulpitu w lectorium (tzw. inkatenacja księgi), zob. Encyklopedia wiedzy o ksiażce, red. A. Birkenmajer et al., Wrocław 1971, kol. 1393.

7 Nazwisko Szwarc występuje w źródłach staropolskich w kilku wariantach: Sworcz, Sworc, Swarcz, Schwarcz, Czarny, Czarni, Niger; zob. Acta consularia Posnaniensia (Akta radzieckie poznańskie). 3, 1502-1506, wyd. K. Kaczmarczyk, Wydawnictwa Źródłowe Komisji Historycznej PTPN, t. 9, Poznań 1948, s. 183.

8 K. Kantak, Bernardyni polscy, t. 1, Lwów 1933, s. 13; K. Kantak, J. Szablowski, J. Żarnecki, Kościół i klasztor bernardynów w Krakowie, Kraków 1938, s. 5.

9 W tym miejscu chciałabym podziękować dr. Jakubowi Kujawińskiemu za cenne spostrzeżenia i uwagi dotyczące analizy duktu pisma i treści noty. 
kolejności, tzn. od strony lewej) układają się w poniższą treść, przy czym również tutaj ostatni wyraz pozostaje zagadkowy:

\section{REBIL IRTSYM}

Liber $m<a>$ ystri

\section{REBIL IRTSYAM AIGROTAIS}

Liber maystri siatorgia (?)

Czwarty wariant rozpisany w dwóch liniach zawiera najpełniejszą informację, jaką zostawił po sobie pierwszy właściciel kodeksu:

\section{REBIL IRTSYAM IMINOREI ZCRAWS ED SICARC}

Liber maystri Ieronimi

Swarcz de Cracis

Notę kończy dewocyjne wezwanie imienia Chrystusa zapisane w formie skrótu: IHS XPVS.

Poniżej zapiski pierwszego właściciela księgi magistra Hieronima znajduje się druga notatka, sporządzona inną ręką prawdopodobnie bibliotekarza krakowskiego klasztoru bernardynów: Vocabularium Katholicon Johannis scilicet Januensis magistri Jeronimi de Cracis Swarcz<j? $><i>u r g a$ pro loco nostro sancti Bernardini in ponte regali extra Cracis (?) 1466. Wynika z niej, iż słownik Catholicon Giovanniego da Genova należący do magistra Hieronima z Krakowa Swarcziurga ${ }^{10}$ (Szwarca?), został przekazany w 1466 roku - zapewne przez samego właściciela - do klasztoru św. Bernardyna na przedmieściu krakowskim Pons Regalis ${ }^{11}$.

Tyle o Hieronimie mówią zapiski proweniencyjne kodeksu. A inne źródła? W aktach miejskich i kościelnych Krakowa, w XV-wiecznych zapisach kronikarskich i epistolograficznych można natrafić na wzmianki dotyczące mieszczanina Jerzego Szwarca dictus Iurga i jego rodziny. Był wieloletnim rajcą krakowskim ${ }^{12}$, w 1442 roku w Budzie otrzymał od króla

${ }^{10}$ Przydomek ten daje się odczytać jedynie jako „syn(a) Jurgi Swarcza”. Jurga to jedna z form imienia Jerzy (Georgius), które pojawia się w źródłach polskich także jako: Jurge Jura, Jurasz, Juraszek i in.; Stownik staropolskich nazw osobowych, red. W. Taszycki, t. 2, Wrocław 1968-1970, s. 98, 504-505.

${ }^{11}$ Krakowskie przedmieście Stradom (Stradomia), gdzie został usytuowany klasztor bernardynów, nosiło pierwotnie również nazwę Most Królewski - łac. Pons Regalis, stąd in Ponte regali.

${ }^{12} \mathrm{~W}$ dokumentach miejskich występuje jako Georgius Swarcz (Iorge Swarcz), przyjęty do rady miejskiej 4 stycznia 1419 roku, pełnił tę funkcję (z przerwami) do 


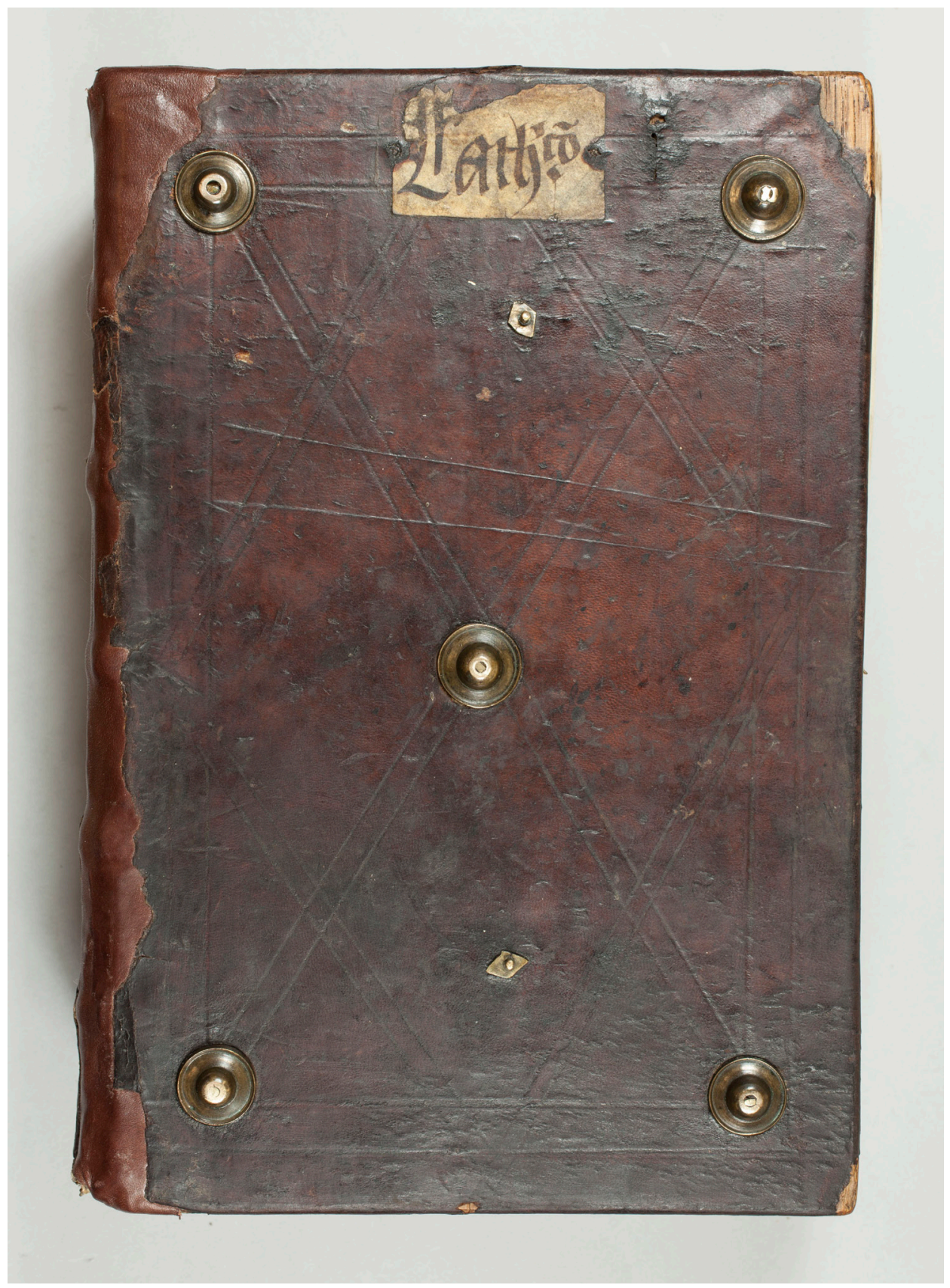

Il. 1. Johannes Januensis de Balbis, Catholicon Źródło: Biblioteka Uniwersytecka w Poznaniu, Rkp. 1717. 


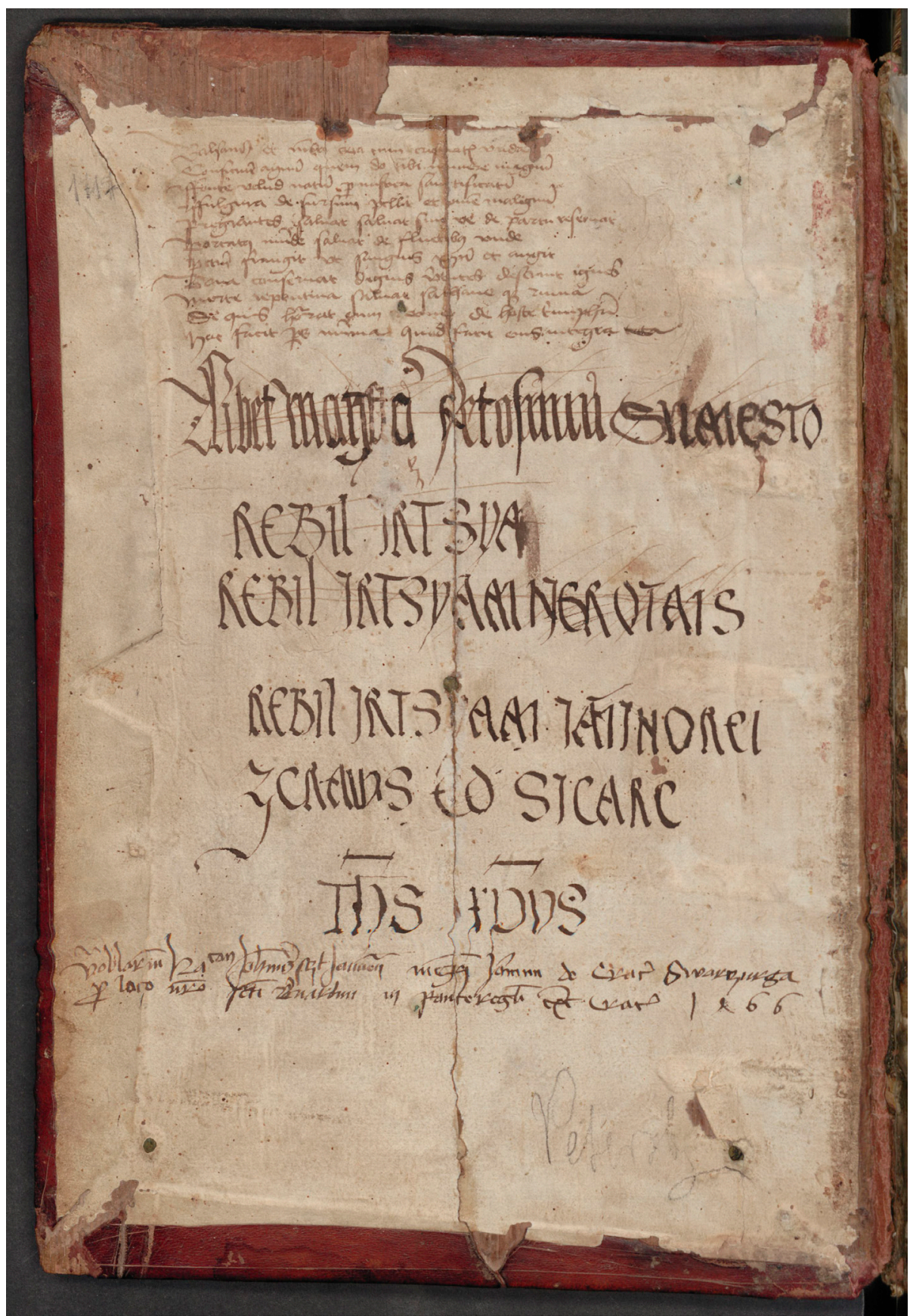

Il. 2. Johannes Januensis de Balbis, Catholicon. Przednia wyklejka oprawy z notami proweniencyjnymi Źródło: Biblioteka Uniwersytecka w Poznaniu, Rkp. 1717. 


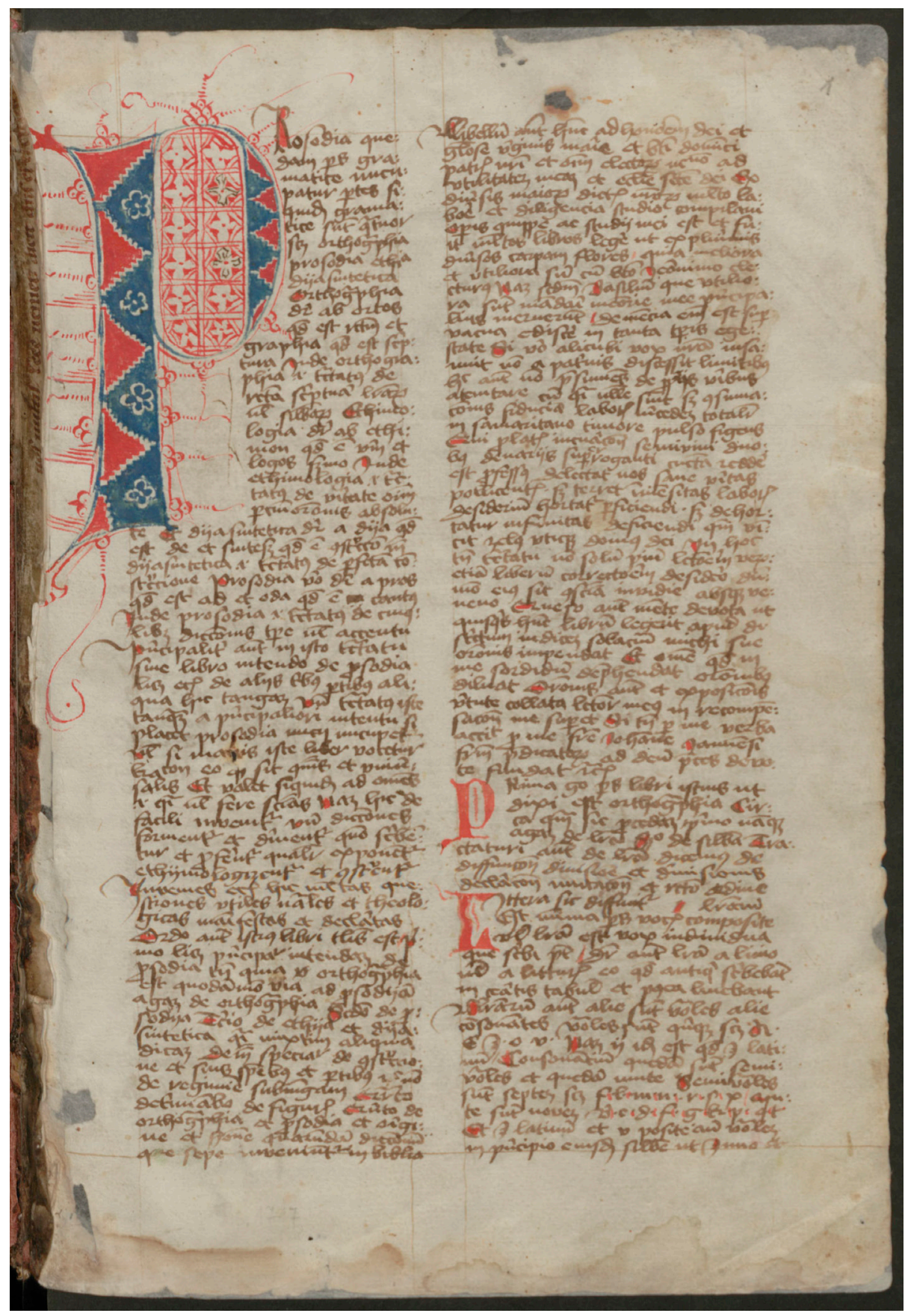

Il. 3. Johannes Januensis de Balbis, Catholicon. Pierwsza karta kodeksu z incipitem Prosodia quaedam pars grammaticae nuncupatur...

Źródło: Biblioteka Uniwersytecka w Poznaniu, Rkp. 1717. 


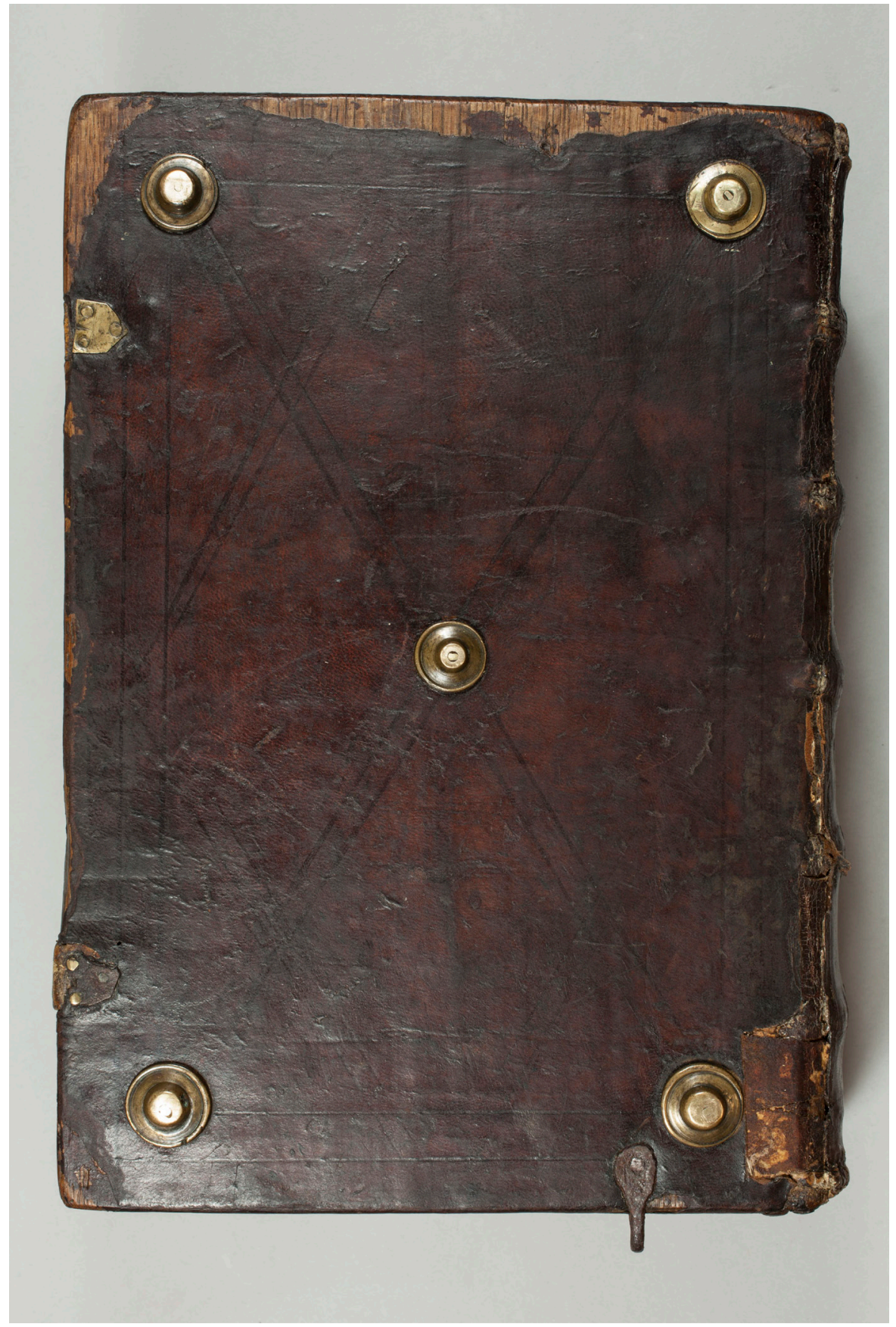

Il. 4. Johannes Januensis de Balbis, Catholicon. Tylna część oprawy z żelaznym kółkiem u dołu - pozostałość po inkatenacji księgi Źródło: Biblioteka Uniwersytecka w Poznaniu, Rkp. 1717. 
Władysława Warneńczyka nobilitację szlachecką i legitymował się odtąd herbem Boże Zdarz ${ }^{13}$. Miał dwie córki (Urszulę i Agnieszkę) oraz trzech synów (Jerzego, Stanisława i Hieronima) ${ }^{14}$. Najwięcej wiemy o pierworodnym Jerzym, absolwencie Uniwersytetu Krakowskiego (bakałarzu) ${ }^{15}$, który zrobił karierę kościelną jako archiprezbiter i pleban kościoła NMP w Krakowie (1450-1493) ${ }^{16}$ oraz dziekan kolegiaty sandomierskiej (od 1450), zmarł w 1494 roku$^{17}$.

Wiadomości o najmłodszym Szwarcu znajdujemy jedynie w aktach krakowskiej wszechnicy. W Metryce Uniwersytetu Krakowskiego, na liście studentów immatrykulowanych na semestr wiosenny 1451 roku, za rektoratu Benedykta Hessego, znalazł się Geronimus Georgii Sworcz de Cracouia $^{18}$, tj. Hieronim, syn Jerzego Szwarca. Z kolei Liber promotionum

1450 roku; Kodeks dyplomatyczny miasta Krakowa, red. F. Piekosiński, t. 1: 1257-1506, Kraków 1879, s. XXXII. Znane są też inne fakty z życia Szwarca: w 1439 roku ufundował kaplicę Bożego Ciała (obecnie Przemienienia Pańskiego) w kościele NMP w Krakowie, Katalog zabytków sztuki w Polsce, t. 4: Miasto Kraków, cz. 2, red. A. Bochnak, J. Samek, Warszawa 1971, s. 2. Ponadto był patronem i kolatorem ołtarza w kościele Wszystkich Świętych, a także wielokrotnym poręczycielem długów znanego żupnika krakowskiego Mikołaja Serafina; Korespondencja żupnika krakowskiego Mikołaja Serafina z lat 1437-1459, wyd. W. Bukowski, T. Płóciennik, A. Skolimowska, Kraków 2006, s. 17.

${ }^{13}$ Album armorum nobilium Regni Poloniae XV-XVIII saec. Herby nobilitacji i indygenatów XV-XVIII w., wstęp, oprac. i edycja B. Trelińska, Lublin 2001, s. 45, nr 8: Jerzy Schwarcz.

${ }^{14}$ O Stanisławie wiadomo jedynie, iż był krakowskim kupcem; córki Szwarca znane są tylko z imienia. Podaję za: Korespondencja żupnika krakowskiego..., s. 17, przyp. 19.

15 Studia rozpoczął w 1437 roku, a osiem lat później otrzymał stopień bakałarza; Metryka Uniwersytetu Krakowskiego z lat 1400-1508, wyd. A. Gąsiorowski, T. Jurek, I. Skierska, przy współpracy R. Grzesika, t. 1, Kraków 2004, s. 177; Najstarsza księga promocji Wydziału Sztuk Uniwersytetu Krakowskiego z lat 1402-1541, wyd. A. Gąsiorowski, T. Jurek, I. Skierska, Warszawa 2011, s. 214.

${ }^{16} \mathrm{Na}$ czas sprawowanych przez niego funkcji w kościele Mariackim przypada budowa ołtarza Wita Stwosza (1477-1489) oraz nowych organów. W 1490 roku ufundował Ogrojec przy kościele św. Barbary; podaję za: B. Przybyszewski, Krakowskie duchowieństwo parafialne przy końcu średniowiecza, „Folia Historica Cracoviensia” 1994, t. 2, s. 32 .

${ }^{17}$ Należał do niewielkiego grona kanoników sandomierskich, wywodzących się z krakowskiego mieszczaństwa; L. Poniewozik, Mieszczanie w średniowiecznych kapitułach kolegiackich na przykładzie Sandomierza $i$ Wiślicy, w: Ecclesia et civitas. Kościót i życie religijne w mieście średniowiecznym, red. H. Manikowska, H. Zaremska, Warszawa 2002, s. 181, 183. J. Wiśniewski podał jedynie szlacheckie pochodzenie Jerzego Szwarca; J. Wiśniewski, Katalog prałatów i kanoników sandomierskich od 1186-1926, Radom 1926, s. 286.

${ }^{18}$ Metryka Uniwersytetu Krakowskiego..., s. 236. 
Wydziału Sztuk krakowskiej uczelni odnotowuje, iż w 1459 roku niejaki Jeronimus de Cracouia uzyskał stopień magistra $\operatorname{artium}^{19}$. Co istotne, późniejszy glosator uniwersytecki dopisał przy imieniu Hieronima cenną informację o jego dalszej profesji: frater ordinis minorum de observancia. Po ukończeniu studiów Szwarc wstąpił zatem do zakonu franciszkanów obserwantów. Oba powyższe przekazy zawarte w źródłach uniwersyteckich odnoszą się zapewne do tej samej osoby, a zarazem właściciela omawianego kodeksu. Jak wynika z treści kolofonu, przepisywanie Catholiconu zostało ukończone w 1457 roku, a więc rękopis ten powstał w okresie przypadającym na ostatni etap studiów Hieronima, prawdopodobnie w środowisku uniwersyteckim - największym w XV wieku „skryptorium” na ziemiach polskich, w którym studentes kopiowali księgi na użytek własny i profesorów ${ }^{20}$. Na tej podstawie można więc przyjąć hipotezę, iż interesujący nas rękopis Catholiconu może być dziełem samego Hieronima.

Notatka frater ordinis minorum de observancia, dopisana w Księdze promocji przy nazwisku magistra Szwarca już po 1459 roku, jak również zapiska w jego kodeksie informująca o przekazaniu tej księgi w 1466 roku do biblioteki klasztoru bernardynów w Krakowie nasuwają wiele pytań dotyczących dalszego etapu życia absolwenta krakowskiej Alma Mater. Przede wszystkim, kiedy i w jakich okolicznościach przywdział franciszkański habit, czy wzmiankują o nim źródła bernardyńskie, w końcu, czy jego imię odnotowuje nekrolog klasztoru, w którym spędził ostatnie lata swojego życia. Jednak aby w pełni i we właściwym świetle zrozumieć zakonną historię Hieronima, trzeba cofnąć się do początku historii polskich franciszkanów obserwantów na ziemiach polskich, która zaczęła się właśnie w Krakowie.

Na czas studiów Hieronima przypadają ważne wydarzenia w dziejach Krakowa i życia religijnego jego mieszkańców. 28 sierpnia 1453 roku, na zaproszenie króla Kazimierza Jagiellończyka i kard. Zbigniewa Oleśnickiego, przybył do miasta franciszkanin Giovanni da Capestrano (1386-1456), znany w Polsce jako Jan Kapistran - charyzmatyczny kaznodzieja pokutny i czołowy reformator Zakonu Braci Mniejszych, jeden z głównych (obok Bernardyna ze Sieny) ideologów i propagatorów

${ }^{19}$ Ksiega promocji Wydziału Sztuk Uniwersytetu Krakowskiego z XV wieku, wyd. A. Gąsiorowski, przy współpracy T. Jurka, I. Skierskiej, W. Swobody, Kraków 2000, s. 47; Najstarsza księga promocji..., s. 223.

${ }^{20}$ E. Potkowski, Produkcja książki rękopiśmiennej w Polsce w XV stuleciu, w: Z badań nad polskimi księgozbiorami historycznymi, red. B. Bieńkowska, Warszawa 1980, s. 14-19; idem, Książka rękopiśmienna w kulturze Polski średniowiecznej, Warszawa 1984, s. 83-94. 
franciszkańskiego obserwantyzmu ${ }^{21}$. Naoczny świadek wydarzeń kanonik Jan Długosz pozostawił w księdze XII swoich Roczników szczegółową relację z kilkumiesięcznego pobytu Jana Kapistrana w Krakowie, który gościł w stolicy do 14 maja 1454 roku. Opisując działalność kaznodziejską zakonnika i dając przy tym wyraz podziwu dla jego talentu oratorskiego, Długosz przekazał też jedną szczególnie cenną informację dotyczącą miejsca zamieszkania włoskiego gościa:

Wielka była z jego przybycia radość między duchowieństwem i mieszkańcami miasta, zaczem lud obojej płci wyszedł przeciw niemu w mnogim tłumie. Na gospodę przeznaczono mu dom Jerzego Sworca $\mathrm{w}$ rynku, a obok kościoła ś. Wojciecha wystawiono mownicę, z której codziennie, zanim większe zimna nastały, po odprawieniu mszy ś. słowo Boże obyczajem swoim w łacińskim języku przez dwie godziny opowiadał, a lud słuchał go cierpliwie i bez utęsknienia; taką bowiem obdarzony był mądrościa, nauką i wymową że zdawało się, jakoby głos jego był z samych niebios pożyczony. Kazania te potem przez drugie dwie godziny ludowi polskim językiem tłumaczono ${ }^{22}$.

Podobny przekaz znajdujemy również w bernardyńskiej kronice Jana z Komorowa z pierwszej połowy XVI wieku, w opisie powitania włoskiego kaznodziei przez króla i krakowian: in domo lapidea domini Georgii Sworcz seu Nigri hospitaverunt et locaverunt ${ }^{23}$. Wspomniany w obu kronikach

${ }^{21}$ Obserwantyzm (łac. observare - przestrzegać, zachowywać) był oddolnym ruchem reformatorskim rozwijającym się w drugiej połowie XIV wieku w klasztorach franciszkańskich, głównie na terenie Italii. Podstawową ideą obserwantyzmu był powrót do ścisłego przestrzegania surowych zasad pierwotnej reguły św. Franciszka. Miano „czterech filarów obserwancji” w historiografii franciszkańskiej otrzymali: Albert z Sarteano, Jakub z Marchii oraz - najwięksi wśród nich - Bernardyn ze Sieny i Jan Kapistran. Ruch obserwancki był reakcją na szerzący się w zakonie w XIV wieku konwentualizm, dopuszczający możliwość łagodzenia reguły założyciela (zwłaszcza w kwestii użytkowania dóbr materialnych) oraz wprowadzania zmian w prawodawstwie zakonu stosownie do wymogów rzeczywistości, w jakiej bracia pracują. Ścieranie się tych dwóch opcji doprowadziło ostatecznie do trwałego rozłamu w Zakonie Braci Mniejszych. W latach 1443-1446 wydzielone zostały dwie autonomiczne kongregacje obserwantów - ultramontańska i cismontańska. Formalny podział na dwa zakony - Zakon Braci Mniejszych Konwentualnych (Ordo Fratrum Minorum Conventualium) i Zakon Braci Mniejszych Obserwantów (Ordo Fratrum Minorum [Regularis] Observantiae) zatwierdził w 1517 roku papież Leon X.

${ }^{22}$ Jana Długosza kanonika krakowskiego Dziejów polskich ksiag dwanaście, wyd. A. Przeździecki, przeł. K. Mecherzyński, t. 5, ks. XII, Kraków 1870, s. 138.

${ }^{23}$ Memoriale Ordinis Fratrum Minorum a fr. Joanne de Komorowo compilatum, wyd. X. Liske, A. Lorkiewicz, MPH V, Lwów 1888, s. 169. 
dominus Jerzy Sworc, który gościł w swojej kamienicy ${ }^{24}$ sławnego „męża Bożego", to najpewniej ojciec Hieronima ${ }^{25}$, ówczesnego studenta Uniwersytetu Jagiellońskiego, późniejszego magistra artium i bernardyna. Można się zatem domyślać, iż kilkumiesięczny kontakt z charyzmatycznym kaznodzieją franciszkańskim miał duży (jeśli nie decydujący) wpływ na wybór dalszej drogi życiowej młodego Szwarca.

Powróćmy jednak do Krakowa lat 1453-1454, żyjącego obecnością włoskiego kaznodziei i - jak podaje Długosz - uzdrowiciela, którego sława przyciągała tłumy: "Zaczem z całego królestwa Polskiego, a nawet z przyległych okolic, garnęło się do Krakowa wielkie mnóstwo ludzi, szukając ratunku w wielu potrzebach i cierpieniach, i dla widzenia męża Bożego. Przeszło sto osób przyjęło wtedy szatę jego zakonu"26. Trudno stwierdzić, w jakim stopniu podana przez Długosza liczba powołanych wówczas bernardyńskich nowicjuszy - zwanych później kapistrańczykami - odpowiada rzeczywistości, a w jakim jest wyrazem nieskrywanej sympatii kronikarza do Kapistrana i jego zakonu. Nie zmienia to jednak faktu, iż najważniejszym i trwałym efektem misji Jana Kapistrana było założenie w stolicy Królestwa pierwszego na ziemiach polskich klasztoru franciszkanów regularnej obserwancji. Ufundowany przez kard. Zbigniewa Oleśnickiego i króla Kazimierza na krakowskim przedmieściu Stradom rozpoczął oficjalnie swoją działalność już 8 września 1453 roku, kiedy to Kapistran i towarzyszący mu bracia oraz nowicjusze zostali wprowadzeni do wybudowanego dla

${ }^{24}$ Kamienica zlokalizowana w południowej pierzei Rynku Głównego, pod numerem 26, na rogu ul. Wiślnej. Została wzniesiona w pierwszej połowie XIV wieku, jako piętrowa i trzytraktowa, w XV wieku rozbudowana. Pobyt wielkiego kaznodziei w murach kamienicy upamiętnia narożna późnobarokowa rzeźba św. Jana Kapistrana, od której pochodzi nazwa kamienicy pod św. Janem Kapistranem (zwanej też Starą Kamienica, Książęcą bądź Podpartą); Katalog zabytków sztuki w Polsce, t. 4: Miasto Kraków, cz. 10, red. M. Myśliński, Warszawa 2005, s. 86-88.

${ }^{25}$ W komentarzach do najnowszego przekładu Roczników Jana Długosza, w odsyłaczu do postaci Jerzego Szwarca znalazła się informacja, iż jest to syn Jerzego, rajcy krakowskiego, dziekan sandomierski, archiprezbiter i pleban NMP w rynku krakowskim, zm. 1494. Trudno zgodzić się z tą identyfikacją ponieważ nie ma przekazu źródłowego, który by ją potwierdzał. Wydaje się niemożliwe, aby kronikarz krakowski kanonik i naoczny świadek wydarzeń, opisujący pobyt Kapistrana z dużą dokładnością - mógł pominąć tak ważny i interesujący szczegół jak profesja duchowna (i związane z nią urzędy) właściciela kamienicy. Powyższe twierdzenie można więc przyjąć jedynie za hipotezę; zob. Jana Długosza Roczniki czyli Kroniki sławnego Królestwa Polskiego, Księga dwunasta 1445-1461, red. J. Wyrozumski, Warszawa 2009, s. 193; por. także Polska Jana Długosza, red. H. Samsonowicz, Warszawa 1984, s. 489.

${ }^{26}$ Jana Dtugosza kanonika..., ks. XII, s. 138. 
nich drewnianego kościoła pod wezwaniem św. Bernardyna ze Sieny i klasztoru ${ }^{27}$.

W historiografii zakonu utrwalił się przekaz o znacznym udziale przedstawicieli krakowskiego środowiska uniwersyteckiego w pierwszym pokoleniu nowicjuszy, zwłaszcza w gronie kapistrańczyków. Przekonanie to powtarzali kolejni historycy zakonu, szczególnie Kamil Kantak, który w swojej monografii zamieścił bodaj najbardziej entuzjastyczną opinię na ten temat: „Mało który zakon w Polsce rozpoczynał istnienie z takim zastępem wykształconych ludzi jak właśnie Bernardyni. Można by go po prostu nazwać zakonem uniwersyteckim. Studenci, bakałarze, magistrowie przywdziewali bury habit obserwancki" ${ }^{28}$. Pogląd ten należy traktować jednak z pewną rezerwą, ponieważ współczesne (średniowieczne) źródła zakonne nie potwierdzają tak licznego udziału studentów i absolwentów krakowskiej uczelni w klasztornej rekrutacji, jak życzyliby tego sobie późniejsi historiografowie. Dwa podstawowe w tym względzie źródła (prowadzone do lat 30. XVI wieku) - Kronika Jana z Komorowa i nekrolog Innocentego z Kościana - odnotowują imiennie łącznie 29 braci, którzy wstąpili do wspólnoty z wykształceniem uniwersyteckim: 12 magistrów artium i 17 bakałarzy ${ }^{29}$. W tym gronie na czołowym miejscu znaleźli się trzej wybitni profesorowie - wykładowcy popularnej w średniowieczu sztuki pamięci (ars memorativa), krzewiący ją aktywnie także w zakonie: Stanisław Korzyb, Marcin (Antoni) z Radomska oraz Jan Szklarek ${ }^{30}$. Listę tę należy uzupełnić o dwóch zakonników wymienionych jedynie

27 To właśnie od wezwania macierzystego kościoła i klasztoru św. Bernardyna (kanonizowanego już w 1450 roku) utrwaliła się w Polsce lokalna nazwa zakonu bernardyni. Poza terenami Korony i Litwy ta zwyczajowa nazwa stosowana była jedynie w Austrii i na Węgrzech; M. Maciszewska, Klasztor bernardyński w społeczeństwie polskim 1453-1530, Warszawa 2001, s. 13. Dzieje fundacji krakowskiego klasztoru opisał szczegółowo K. Kantak, op.cit., s. 10-13; K. Kantak, J. Szablowski, J. Żarnecki, op.cit., s. 11-13.

${ }^{28}$ K. Kantak, op.cit., s. 279. Dopiero M. Maciszewska podała w wątpliwość pogląd o wyraźnie uniwersyteckim charakterze bernardyńskiej rekrutacji w XV wieku M. Maciszewska, op.cit., s. 145.

${ }^{29}$ Opracowana przez M. Maciszewską tabela zawiera imiona 28 zakonników oraz informację o pełnionych $\mathrm{w}$ zakonie funkcjach i miejscu śmierci. Brakuje w niej natomiast Szymona z Lipnicy, bakałarza z 1457 roku, o którym wspomina zarówno bernardyńska kronika, jak i nekrolog; zob. M. Maciszewska, op.cit., s. 144, tabela 14. Por. A. Szulc, Homo religiosus późnego średniowiecza. Bernardyński model religijności masowej, Poznań 2007, s. 48.

${ }^{30}$ Zagadnienie polskiej, zwłaszcza bernardyńskiej mnemotechniki średniowiecznej badał wnikliwie R. Wójcik, "Opusculum de arte memorativa” Jana Szklarka. Bernardyński traktat mnemotechniczny z 1504 roku, Poznań 2006; por. inne prace tego autora. 
w źródłach uniwersyteckich. Pierwszy z nich to Wojciech z Szadka, który został wpisany na uniwersytet w 1475 roku, a 10 lat później uzyskał stopień bakałarza (in gradum bacalariatus promotus) ${ }^{31}$. Drugim bernardynem ze stopniem uniwersyteckim, którego udało się zidentyfikować na podstawie zapisów Liber promotionum krakowskiego Wydziału Sztuk, to interesujący nas Hieronim Szwarc z Krakowa, który w 1459 roku uzyskał promocję ad gradum magisterii in artibus ${ }^{32}$. Zastanawiające jest jednak milczenie źródeł zakonnych na temat brata, wydawałoby się, "cennego" dla wspólnoty, ze względu zarówno na stopień naukowy, jak i na pochodzenie oraz rodzinne koneksje. Nekrolog polskiej prowincji odnotowuje śmierć dwóch braci o tym imieniu, przy czym obaj zakończyli studia bakalaureatem. W klasztorze krakowskim zmarł (data nieznana) brat Hieronim, kapłan, a w Lublinie Hieronim z Krakowa, również kapłan. Być może właśnie on jest tożsamy z Hieronimem Szwarcem, a zakonny historiograf jedynie błędnie odnotował jego stopień naukowy? To pytanie pozostanie już bez odpowiedzi. Nie ulega jednak wątpliwości, iż wobec stosunkowo niedużej liczby znanych z imienia absolwentów krakowskiej wszechnicy, którzy znaleźli się w gronie kapistrańczyków bądź poszli w ich ślady w latach późniejszych, odnalezienie w przekazach źródłowych i dopisanie do tej listy choćby jednego bernardyna wywodzącego się z kręgu uniwersyteckiego ma istotne znaczenie badawcze.

Poza wspomnianą liczbą 31 zidentyfikowanych absolwentów (i wykładowców) uczelni do grona braci wywodzących się z kręgu uniwersyteckiego należy zaliczyć także wielu bezimiennych, którzy wstępując do klasztoru, mieli za sobą jedynie studencki „epizod”, nieuwieńczony nawet najniższym stopniem bakałarza artium. Biorąc pod uwagę nieudokumentowaną i nieokreśloną liczbę braci w tej „,kategorii”, jak również braki i nieścisłości danych, jakie zdobywali bernardyńscy kronikarze z poszczególnych klasztorów, można jednak przyjąć, iż udział intelektualnej elity Krakowa w klasztornej rekrutacji w pierwszych latach działalności zakonu był znaczny. To bowiem bracia-,,, akademicy" mieli zasadniczy wpływ na poziom intelektualny bernardyńskiego duszpasterstwa, ponieważ z racji wykształcenia właśnie im przydzielano w klasztorach funkcje gwardianów, kaznodziejów, mistrzów nowicjatu oraz lektorów (wykładowców klasztornych studiów teologicznych), a być może także bibliotekarzy.

${ }^{31}$ Metryka Uniwersytetu Krakowskiego..., s. 376: Albertus Petri de Schadek <baccallarius, ingressus religionem Bernardinorum religiose vixit>; Najstarsza księga promocji..., s. 246: Albertus de Schadek <frater Minorum de observancia>, <religiosissimus, avunculus sequencium compatriotarum $>$.

${ }^{32}$ Zob. przypis 12. 
Przedstawiona geneza zakonu franciszkanów obserwantów na ziemiach polskich ukazuje kodeks Hieronima i jego losy w innym świetle i szerszej perspektywie, nadając mu szczególnego, jeśli nie wyjątkowego znaczenia - księgi należącej do człowieka, który poznał Jana Kapistrana. Księgi będącej własnością (może nawet dziełem rąk) absolwenta Uniwersytetu Jagiellońskiego, reprezentanta licznego grona krakowskich studentów, którzy przejęci nauczaniem włoskiego kaznodziei i franciszkańskimi ideałami, wstąpili w szeregi bernardynów. W końcu księgi, która już od 1466 roku należała do pierwszego polskiego księgozbioru franciszkanów obserwantów. Kodeks z kopią popularnego w średniowieczu słownika łaciny, „zwykły” podręcznik łacińskiej gramatyki dzięki historii właściciela okazał się księgą niezwykłą.

\author{
ALICJA SZULC
}

\title{
Master Hieronim Szwarc codex. A contribution to the history of the oldest book collection of the Franciscans/Bernardines in Cracow
}

\begin{abstract}
Aвstract. The present article attempts to present, with an example of a medieval codex, the value and significance of the research on provenance of historical book collections. This is the case with the book under review: it is a detailed description of the Codex from the book collection of Poznan University Library - the fifteenth century copy of Catholicon by Giovanni Balbis of Genoa, a popular and commonly used in the Middle Ages dictionary and text book (primer) of Latin grammar. The manuscript, modestly illuminated and finished in 1457, is the only specimen of a hand-written chained book (liber catenatus) currently held in the Library's collection. The codex is unique and extremely valuable not only on account of its content, but rather because of its first owner (possibly the copyist of the original book) - Hieronim Szwarc, Master of Arts or atrium magister of the Jagiellonian University, and later a monk at Priory of Franciscans/Observants, also known as the Bernardines, in Cracow-Stradom. As it follows from the analysis of the provenance notes placed on the front side of the flyleaf of the original binding of Catholicon, as well as from available historiographical sources, both academic and monasterial, Hieronim was a son of a well-known Cracow burgher Jerzy Szwarc who, at the turn of the 1453/1454, hosted in his tenement house in the market the famous Italian penitential preacher and reformer of the Franciscan Order John of Capistrano and accompanying friars. The relevant source study has revealed that the codex was in possession (or was possibly even the work) of the Jagiellonian University graduate, and at the same time a Capistrano-follower,
\end{abstract}


i.e. a member of the numerous circle of students of the Cracow Academy who, inspired by sermons delivered by John of Capistrano, joined the Franciscan/Observants Order and the first priory of the Bernardines in Poland founded in Cracow in 1453. Another ownership note provides, in turn, a statement that Master Hieronim's codex was handed over (by the owner?) to the library of this particular priory in 1466 . It belongs then to the oldest Bernardine book collection in Poland.

Key words: Giovanni Balbis of Genoa, Catholicon, Hieronim Szwarc, Kraków, the Bernardines, Cracow University in the 15thc., liber catenatus, medieval codices, medieval manuscripts, provenance research. 